OPEN ACCESS

Edited by:

Maija Lampela,

National University of Singapore,

Singapore

Reviewed by:

Susanti Withaningsih,

Universitas Padjadjaran, Indonesia

Nurhayati Abdul Malek,

Universiti Teknologi MARA Puncak

Alam, Malaysia

*Correspondence:

Alinda F. M. Zain

alindafm@apps.ipb.ac.id

Specialty section:

This article was submitted to

Environmental Economics and

Management,

a section of the journal

Frontiers in Environmental Science

Received: 30 September 2021

Accepted: 17 January 2022

Published: 14 February 2022

Citation:

Zain AFM, Pribadi DO and Indraprahasta GS (2022) Revisiting the Green City Concept in the Tropical and Global South Cities Context: The Case

of Indonesia.

Front. Environ. Sci. 10:787204. doi: 10.3389/fenvs.2022.787204

\section{Revisiting the Green City Concept in the Tropical and Global South Cities Context: The Case of Indonesia}

\author{
Alinda F. M. Zain ${ }^{1,2 *}$, Didit O. Pribadi ${ }^{3,2}$ and Galuh S. Indraprahasta ${ }^{3,2}$ \\ ${ }^{1}$ Department of Landscape Architecture, Faculty of Agriculture, IPB University, Bogor, Indonesia, ${ }^{2}$ Center for Regional System \\ Analysis, Planning and Development, IPB University, Bogor, Indonesia, ${ }^{3}$ National Research and Innovation Agency (BRIN), \\ Jakarta, Indonesia
}

Urban areas play a key role in reaching global sustainability as they produce a high amount of waste and emissions, consume a lot of resources, and perform as the prime mover of the global economy. Unsustainable urbanization will generate multidimensional impacts on the earth's socio-ecological system that is nearly impossible to be managed. As a preemptive action, urban sustainability has been considered as one of the most important targets in the Sustainable Development Goals. Within this context, the green city has emerged as a widely adopted concept around the globe. In the Global North, the concept of a green city has been incrementally developed as efforts to mainstream green infrastructure and nature-based solutions approaches in supporting ecosystem services. Quite the contrary, in the Global South cities, due to their rapid and vast urbanization process, the green city has been fragmentally adopted. Previous studies have proposed three factors, i.e., urbanization, biophysics, and governance, underlying the different approaches of green city development between cities in the Global North and South. Still, more studies are needed to explicate these factors and how these will in turn shape a particular green city trajectory in Global South cities. This study aims to respond to these questions based on green city experimentation in Indonesia. An exploratory study was done based on a literature review and participant observation. The results exhibit that the green city program in Indonesia largely focused on the development of green open spaces which has ultimately failed to improve the urban environment and sustainability. Incorporating local socio-ecological aspects coupled with integrated multi-level and multi-actors' governance is recommended to increase the green city performances.

Keywords: green city, geographical situatedness, global south, Indonesia, urban sustainability

\section{INTRODUCTION}

Urban areas have become a key geographical area to address sustainability issues due to their massive ecological implications, i.e., waste and emission production and ecological footprint, that have not only affected in-situ environment but also the global environment (Acuto et al., 2018; Zinkernagel et al., 2018). On the other hand, urban areas also strongly interlinked with global socio-economic dynamics as almost $60 \%$ of the world's population live in these particular areas (UNDESA, 2018) and they function as the key locus of global economic growth (Acuto et al., 2018; World Bank, 2020). Less 
surprisingly, urban sustainability has become an increasingly prominent topic of discussion, including in the global policy discourse where urban areas or cities are part of the United Nations Sustainable Development Goals (UN SDGs).

Amid the rising prominence of urban sustainability agendas, the green city has come to the fore as one of the most widely adopted concepts across the globe, both in the Global North and South. At the outset of green city's experimentation, more emphasis was given to minimizing environmental impact by increasing efficient use of energy, water, and land as well as reducing waste and emissions (EIU, 2012; Liendfield and Steinberg, 2012; Venkatesh, 2013).

Along with the rising global challenges, especially within the context of climate change, the socio-ecological approach has gained increased traction in the current iteration of green city's adoption. Natural processes (i.e., water, nutrient, energy, and carbon cycles) have been more carefully considered to derive ecosystem services (ES) for supporting human well-being (Elmqvist and Mcdonald, 2013). In particular, green infrastructure (GI) and nature-based solutions (NBS) have become two major approaches to operationalize ES in cities as both approaches focus on the integration between nature and artificial-human systems (Nesshöver et al., 2017; Pauleit et al., 2017).

As the intellectual origin of the green city concept, GI and NBS approaches have been developed rapidly in Global North cities. Within this particular geographical setting, developing multifunctional green spaces and their integration with grey infrastructure are increasingly required as the future cities are planned to be more compact (Hansen et al., 2019). As part of this, the development of technology is viewed to be crucial in further enhancing GI and NBS approaches. Currently, the "mixed" concept of smart-compact-green cities has emerged as a renewed initiative of green cities to achieve urban sustainability in an increasingly complex environment (Artmann et al., 2017; Richter and Behnisch, 2018).

Cities in the Global South, however, are still falling behind in implementing this newest iteration of the green city concept, especially in adopting ES, GI, and NBS in urban planning. Some researchers have conducted comparative studies of green city adoption, particularly between cities in Asia and other developing countries and cities in the Global North. Shen and Fitriaty (2018), for instance, reveal that green cities in Asia mainly focus on developing green buildings, green technology, and green open spaces without necessarily linking these initiatives to the existing urban sprawl issue. Meanwhile, the combination of green and smart cities has been partly developed in cities in Asian developed countries such as China, Japan, Korea, and Singapore. In Egypt and India, the green city was recently promoted as a new approach that is linked to urban planning (Pankaja and Nagendra, 2015; El Ghorab and Shalaby, 2016).

While previous studies have highlighted the gap in green city development and implementation between cities in the Global North and South, limited attention has been given to the factors causing this gap. In this study, our primary attention is green city experimentation in the Global South. Shen and Fitriaty (2018) and Lechner et al. (2020), in particular, have proposed three underlying factors that may strongly affect the trajectory of green city in the Global South, i.e., urbanization, biophysics, and governance. The urbanization factor highlights the issue of urban sprawl and high population density, whereas the biophysics factor focuses on the issue of climate change and its relations with the local climate condition. Meanwhile, the governance factor mainly points out the issue of fragmented governance and the lack of public participation.

Still, how these factors have affected the adoption and application of green cities remain uncovered. Further empirical investigations are therefore needed. Against this backdrop, the main objective of this paper is to explore the adoption of the green city concept in Indonesia over the last decade through the lens of urbanization, biophysics, and governance aspects. The Indonesian government formally launched the "Green City Development Program" or Program Pengembangan Kota Hijau (P2KH) in 2011. This program ran until 2020 with a total of 174 participating localities by the end of the program. This paper address two questions in particular: How has the green city concept been adopted in Indonesia by means of the $\mathrm{P} 2 \mathrm{KH}$ program? And, based on this assessment and considering the context specifics of Indonesia, how should the green city concept be further developed? A thorough assessment was done to gauge the effectiveness of the program as well as to gain some valuable lessons learned from the program in achieving urban sustainability goals. This step is pivotal to defining a more refined trajectory of green cities that is attuned to the localized political and socio-ecological dynamics. This study can offer a reference for green city development in the Global South that has more or less similar characteristics to Indonesia.

\section{GREEN CITY CONCEPTION AND ITS EVOLUTION}

The origin of the green city concept can be traced back to the early $20^{\text {th }}$ century, particularly rooted in the existence of urban subsistence gardens in the United States (US) metropolitan areas in the 1900s (Moore, 2006). These gardens, however, were not regarded as part of urban landscapes, but as a temporary crisis response during World War I and the Great Depression period (Kahn, 1982; Warner, 1987). Within this period, urban inhabitants were allowed to farm to secure food supply. The history of urban gardens seems to have been forgotten after the 1940s when the situation had relatively stabilized. As a result, these gardens gradually dissolved in the urban environment as they were viewed as a part of more rural landscapes (Moore, 2006).

The green city concept has revived and gained a new momentum, particularly after the unfolding of sustainable development ideas as declared by the World Commission on Environment and Development in 1987 (El Ghorab and Shalaby, 2016). The rapid pace of industrialization and urbanization has, in particular, been regarded as two major sources of global unsustainability (Lengeweg et al., 2000; Li and Lin, 2015). Therefore, various notions, notably, green city, eco-city, and livable city, have appeared as intertwining concepts to 
mainstream sustainable development in urban areas (Liendfield and Steinberg, 2012; Pace et al., 2016). While eco-city focuses on urban ecological health and livable city emphasizes urbanites' well-being, green city pays particular attention to the relationship between the environment and human systems within the urban context.

There are at least two main factors underlying the conceptualization of a green city. First, from the consumption perspective, the concern is to reduce the demand for natural resources and services as well as waste and emission production. Second, from the production perspective, the main attention is to invest in the improvement of nature and the environment to support a better quality of life. Combining these two perspectives, the green city concept is mainly concerned with the planning and management of green resources and materials, green community, green open spaces, green waste, green transportation, and green building in an integrated manner (Liendfield and Steinberg, 2012). However, some iterations and modifications occurred during the concept implementation, adjusting to the changes of urban issues and challenges as well as to the development of human knowledge and technology.

As the green city concept was originally produced and developed in and from European and US cities, its transformation can be clearly traced in those cities. Increasing economic prosperity in the Global North has been followed by people's increasing awareness concerning quality of life given the rising issues of environmental degradation and climate change. This has then led to a stronger commitment to developing new ways to reduce waste and emission production, generate clean energy and clean water, and increase energy and water use efficiency. Furthermore, the green city concept has been also incorporated into urban planning through developing compact city scenarios so as to reduce human mobility. The notion of a compact city implies the efforts to support efficient mobility, energy use, and reduced emission production (Artmann et al., 2017; Richter and Behnisch, 2018). However, these approaches were regarded as insufficient as recent research findings reveal that comprehending and restoring natural processes (i.e., the cycles of water, carbon, nutrient, and energy) are crucial to address environmental and climate change issues (Schwarz et al., 2017). Accordingly, the green city concept has experienced a paradigm shift. In this newest iteration, humans and their products should live in balance with nature, including all living organisms, and their habitat (Breuste et al., 2020).

The term ecosystem services (ES) has emerged as a key lens that is considered to be able to bridge the human and natural systems (MEA, 2005). Various concepts have been developed to operationalize ecosystem services in cities, in which two concepts in particular, i.e., green infrastructure (GI) and nature-based solutions (NBS), have probably become the most popular ones (Pauleit et al., 2017). GI has been integrated into urban planning through developing green hubs, ecological corridors, restored habitats, and artificial features to assist and enhance natural processes, buffer zones, and multifunctional zones (EC, 2013). Meanwhile NBS, although it is still new and underdeveloped, focuses on mainstreaming nature to deal with the environment and climate change issues by restoring or mimicking the natural process in cities (Pauleit et al., 2017). In these approaches, mainstreaming biodiversity conservation has been encouraged as living organisms are viewed to be essential in supporting and facilitating natural processes (Aronson et al., 2017; Xie and Bulkeley, 2020). Both approaches need a transdisciplinary and multistakeholder approach, focusing on landscape, biodiversity, and human well-being, and integration with urban agendas and urban-grey infrastructures. Meanwhile, environmental justice has been also taken into consideration as ecosystem services are deemed to be a part of public services that should benefit all groups of citizens at an equal basis (Derkzen et al., 2017; GarciaLamarca et al., 2021).

The role of technology to support multifunctional GI or NBS has also become increasingly substantial (Hansen et al., 2019). Various forms of information and communication technology (ICT) have been widely used to monitor environmental quality, including air quality, water quality, water discharge, transportation, and waste disposal. Some other technologies, including solar cell electricity, bio-fuel, and bio-energy, have also been deployed to produce clean energy. In terms of green building, some innovations in modern architecture have been developed to increase energy and water use efficiency as well as to reduce waste production. As a result, the intertwined notions of smart-compact-green cities have been promoted as a renewed concept to reach urban sustainability in the Global North (Artmann et al., 2017).

Meanwhile, the adoption of green cities in the Global South seems to be more challenging due to different socio-ecological contexts. For instance, unlike urban areas in the Global North that have developed in a gradual fashion, the urbanization process in the Global South has occurred at a much faster rate within a much shorter period of time. This urban expansion has been mainly driven by private and foreign investment, intended to propel economic development (Dahiya, 2012). On the other hand, government authorities, in most cases, have a lack of control over the implementation of spatial planning. As a result, urban physical expansion has sprawled in all directions without a clear pattern, encroaching the city's surrounding rural areas (Estoque and Murayama, 2015; Pribadi and Pauleit, 2015). This sprawling process has been accelerated by the increasing land prices coupled with declining environmental quality in the urban core, thus pushing people to live in the outskirts. As a result, commuting has become a common phenomenon that leads to a longer time of travel, thus producing emissions that continue to increase over the years.

Within this Global South cities setting, efforts to develop green open spaces, manage waste and emissions, and reduce mobility become more complex (Shen and Fitriaty, 2018). Extending green open spaces has been hampered by land scarcity and rising land prices. Waste and emission have been badly managed due to high population numbers and high density that leads to congestion and waste disposal issues. In the same token, reducing mobility has also been difficult to implement as urban sprawl continues to facilitate commuting behavior. On the other hand, issues concerning conserving biodiversity and increasing human well-being are still below the radar. It is therefore unsurprising that the new approaches such ES, GI, and NBS have not been 
adopted by Global South cities, except for some cities in China (Hardiman, 2020).

It is also worth noting that in the case of developing countries located in the tropical zones, the application of the concepts such as ES, GI, and NBS can become more complicated since these countries have a rich biodiversity and heterogeneous habitat. In addition to this, cities situated in these zones are also highly vulnerable to climate change, especially in terms of sea-level rise, rainstorms, flooding, landslides, and drought (Lechner et al., 2020). Coupled with uncontrolled sprawling cities and limited capacity of governance, pressures caused by climate change will put a lot of urban inhabitants at risk.

While the specific settings of Global South cities as discussed above call for a different path towards green cities, another challenge that may occur relates to the environmental visioning of green cities. As has been criticized by GarciaLamarca et al. (2021), the green city label in several cities, mainly in the Global North, has been also deployed with the intention to build a city's brand that can attract global actors and investment vis-à-vis improving the socio-ecological quality of a city. Such orientation can facilitate market-led greening that may result in widening socio-spatial inequalities. This "green boosterism" also applies to several Asian cities (Leducq and Scarwell, 2020), especially in Asian developed countries, where smart-green cities have been emphasized (Shen and Fitriaty, 2018) regardless of the continuation of urban sprawl, and its adverse socio-ecological impact.

Taken together, there is a need to arrive at a better understanding of the unique socio-ecological issues in the Global South cities that co-shape the different trajectories of green cities. In this paper, particular emphasis is given to uncovering three distinguished aspects: urbanization, biophysics, and governance (Lechner et al., 2020). In our view, the variegated geographical contexts should be of concern, as the failure to comprehend and manage these would lead to a failure to fully benefit from the adoption of the green city concept.

\section{THE POLICY CONTEXT OF INDONESIA'S URBAN SUSTAINABILITY AGENDA}

Indonesia's rapid economic growth combined with rapid urbanization has led to pressures on the environment (Jafari et al., 2012; Ahmed et al., 2019). Indonesia is the third largest country in Asia in terms of population and is one of the world's biggest polluters (Jambeck et al., 2015; Tarigan and Sagala, 2018). Coping with ever rising environmental challenges and being part of international communities, Indonesia has adopted a number of key global environmental agendas into its national policy circles. In this section, our intention is not to provide an exhaustive review of the global environmental (or more broadly, sustainability) agenda. Rather, we aim to show what we view as some representative examples of these agendas and how the Indonesian government has localized such agendas accordingly.

The first worldwide event that became an important milestone for environmental mainstreaming would be the 1992 Earth Summit that was held in Rio de Janeiro, Brazil. This summit was held on the occasion of the $20^{\text {th }}$ anniversary of the first United Nations (UN) Human Environment Conference in Stockholm, Sweden, in 1972. Taking part in this Earth Summit, Indonesia was among the participating countries that adopted Agenda 21, a comprehensive plan of action to build a global partnership for sustainable development in the $21^{\text {st }}$ century (KLH, 1997). Agenda 21 was one of the major achievements that resulted from the Earth Summit besides, among others, the United Nations Framework Convention on Climate Change (UNFCCC), the Convention on Biological Diversity, and the Declaration on the Principles of Forest Management. Following up its commitment toward this global agenda, in 1997, and Indonesia published the National Agenda 21 containing directions to insert sustainable development principles into the national development planning $(\mathrm{KLH}$, 2002). This document was later followed by the Sectoral Agenda 21 which was published in 2000 (KLH, 2002). This sectoral agenda document outlines a more detailed direction for different sectors, including mining, energy, human settlement, tourism, and forestry.

Indonesia's participation continues to persist to the presentday UN SDGs. Having experience in adopting the previous global agenda, including Agenda 21 and Millennium Development Goals (MDGs), the Indonesian government has elaborated the seventeen goals of SDGs in the development planning documents through the issuance of the Presidential Regulation (Peraturan Presiden) 59/2017 on the Implementation of SDGs' Achievement. As mandated by this regulation, Indonesia has also published the Action Plan of SDGs at the national and provincial levels (Rencana Aksi Nasional/Daerah Tujuan Pembangunan Berkelanjutan).

The country's achievement of SDGs at the Southeast Asian level was, however, still relatively below the region's average overall score (Alisjahbana and Murniningtyas, 2018). Among the total seventeen goals, Indonesia had a higher score vis-à-vis the region for eight goals (Table 1). Meanwhile, the $11^{\text {th }}$ SDG that specifically relates to urban development, i.e., "Sustainable Cities and Communities", was among those that had lower scores than the region's value. Despite not being explicitly mentioned in any government publications, some experts emphasized that sustainable cities should be among the goals of SDGs that are put as a top priority in the Indonesian context (Sachs, 2015; Alisjahbana and Murniningtyas, 2018).

In addition to SDGs, another key global environmental agenda adopted by Indonesia is the 2015 Paris Climate Agreement. The Paris Climate Agreement is the most recent agreement within the framework of the UNFCCC. One of the main aims of the agreement is to maintain the increase in the global average temperature to well below $2^{\circ} \mathrm{C}$ above the pre-industrial levels. Based on this, Indonesia has ratified the Paris Agreement in New York in 2016 and committed to reducing its greenhouse gas (GHG) emissions target by $29 \%$ against a 2030 business-as-usual (BAU) scenario and by up to $41 \%$ subject to international assistance for finance, technology transfer, and capacity building (Masripatin et al., 2017). To this end, five sectors have been set as priority areas for reducing this GHG emissions target, i.e., forestry and peatlands, agriculture, 
TABLE 1 | Score of SDGs of Indonesia in 2015

\begin{tabular}{|c|c|c|c|}
\hline SDGs & & Indonesia & Southeast asia (average) \\
\hline 1 & No Poverty & 76.87 & 83.70 \\
\hline 2 & Zero Hunger & 44.82 & 47.10 \\
\hline 3 & Good Health and Well-being & 53.79 & 61.24 \\
\hline 4 & Quality Education & 73.83 & 70.06 \\
\hline 5 & Gender Equality & 62.09 & 55.76 \\
\hline 6 & Clean Water and Sanitation & 79.10 & 80.97 \\
\hline 7 & Affordable and Clean Energy & 61.78 & 58.49 \\
\hline 8 & Decent Work and Economic Growth & 63.71 & 59.55 \\
\hline 9 & Industry, Innovation, and Infrastructure & 21.52 & 24.27 \\
\hline 10 & Reduced Inequalities & 66.18 & 68.64 \\
\hline 11 & Sustainable Cities and Communities & 48.80 & 56.28 \\
\hline 12 & Responsible Consumption and Production & 46.41 & 39.86 \\
\hline 13 & Climate Action & 83.96 & 69.84 \\
\hline 14 & Life Below Water & 42.80 & 37.29 \\
\hline 15 & Life on Land & 33.65 & 46.22 \\
\hline 16 & Peace, Justice, and Strong Institutions & 59.51 & 56.37 \\
\hline 17 & Partnerships for the Goals & 8.57 & 21.18 \\
\hline All SDGs & & 54.40 & 54.60 \\
\hline
\end{tabular}

Source: Alisjahbana and Murniningtyas (2018).

The bold values (54.40 and 54.60) represent the total scores of SDGs of Indonesia (54.40) and Southeast Asian countries (54.60).

energy and transportation, industry, and waste. Cities and urban areas are not specifically mentioned here, but, to a limited extent, are partially inserted in the energy, and transportation as well as waste sectors (Masripatin et al., 2017; Wijaya et al., 2017).

Another sustainability agenda or concept brought from elsewhere into the Indonesian policy context is strategic environmental assessment (SEA). Historically, it came into existence in western countries, particularly in 1969 when the Congress of the US adopted the National Environmental Policy Act (NEPA). Later in 1985, this system of assessment was introduced in Europe with the implementation of the Environmental Impact Assessment (EIA) Directive (85/337/ EEC) to a wide range of public and private projects. SEA has been used as a means to integrate environmental and social consideration into policy, plan, and program making. In Indonesia, SEA has been formally adopted through Law (Undang-Undang) 32/2009 on Environment Protection and Management. This umbrella regulation was later clarified through the issuance of Government Regulation (Peraturan Pemerintah) 46/2016 on the Procedure for the Implementation of SEA and of Ministry of Environmental Affairs and Forestry Affairs Decree (Peraturan Menteri) 69/2017 on the Implementation of Government Regulation 46/2016. SEA has become a mandatory assessment tool for all strategic public policies at the national, provincial, and local (kota and kabupaten) levels. SEA provisions are thus intended to overcome the void that policies, plans, and/or programs in Indonesia have mostly tended to ignore sustainable development principles (Salim and Hudalah, 2020). In this context, SEA can contribute to achieving a more sustainable urban development by means of assessing key local planning documents, notably local spatial planning (both general [RTRW] and detailed plan [RDTR]), local long-term development planning (RPJPD), and local mid-term development planning (RPJMD).
Meanwhile, in terms of urban policy, the New Urban Agenda (NUA) is deemed to be the most recent global framework promulgated by the United Nations Human Settlements Program (UN-HABITAT) to achieve a better and more sustainable future for cities across the globe. The NUA was first adopted in Quito, Ecuador, on 20 October 2016 and works as an accelerator of the SDGs, particularly the eleventh goal. Indonesia has also played an important part in developing the NUA. On 25-27 July 2016, Surabaya, Indonesia's second largest city after Jakarta, hosted the Third Preparatory Committee meeting for drafting the NUA (Salim and Hudalah, 2020). The NUA mandates that all countries must have a national urban policy. To date, there is no such policy in Indonesia. The draft of the so-called National Urban Area Development Policy and Strategy (Kebijakan dan Strategi Pengembangan Kawasan Perkotaan Nasional or KSPPN)' has been in progress within the Ministry of National Development Planning (BAPPENAS) for years but has not yet been officially published. The Ministry of Public Works and Housing (PUPR), on the other hand, has published a partial interpretation of the NUA for the Indonesian context (Sarosa et al., 2017). According to this publication, five areas are prioritized, i.e., access to clean water, percentage of slums, access to proper sanitation, green open space, and preservation of heritage areas.

In the absence of a national urban policy, Indonesia's central government has approached urban development through a variety of programs. One of the most pertinent programs that has a strong environmental dimension would be the "Green City Development Program” or Program Pengembangan Kota Hijau $(\mathrm{P} 2 \mathrm{KH})$. This program can be cast as an example of global policy mobility of urban ideas and planning practices in the Global South (Leducq and Scarwell, 2020). In Indonesia, the green city label was translated as a program that was anchored on the specific mandate outlined in Law 26/2007 on Spatial Planning, i.e., the obligation to provide green open space to at least $30 \%$ of a 
TABLE 2 | Number of participating localities of P2KH.

\begin{tabular}{lcc}
\hline Batch & Year & $\begin{array}{c}\text { Number of participating } \\
\text { localities (accumulation) }\end{array}$ \\
\hline 1 & 2013 & 60 \\
2 & 2014 & 85 \\
3 & 2015 & 112 \\
4 & 2016 & 143 \\
5 & 2017 & 165 \\
6 & 2018 & 174 \\
\hline
\end{tabular}

city's total area. Based on Article 29 of the spatial planning law, the existence of green open space is expected to provide useful ecosystem services to the city (Zain and Kencana, 2010; Joga and Ismaun, 2011).

P2KH kick-started in 2011, initiated by the Directorate General of Spatial Planning, Ministry of Public Works (PU) (Kirmanto et al., 2014). In the first year, 60 municipalities (kota) and regencies (kabupaten) participated in the program. The number of participants increased continuously. With the government institution restructuring that took place in 2015, the Directorate General of Spatial Planning was transferred to the Ministry of Agrarian Affairs and Spatial Planning (ATR). As an immediate result, $\mathrm{P} 2 \mathrm{KH}$ was moved to the Directorate General of Human Settlements, Ministry of Public Works and Housing (PUPR). PUPR (then PU) provided financial and technical assistance to each of the participating localities for four consecutive years. This PUPRinitiated program ended in 2020 with a total of 174 participating localities (Schwarz et al., 2017) (Table 2). After the end of the central government's facilitation, it was expected that this initiative could be sustained by the participating local governments using their own resources. It should be noted that the $\mathrm{P} 2 \mathrm{KH}$ program also included the development of new botanical gardens (kebun raya) in a small number of localities. However, given its minor role within the overall $\mathrm{P} 2 \mathrm{KH}$ program, we do not discuss this further in our paper.

Inspired by green city measurements developed elsewhere, $\mathrm{P} 2 \mathrm{KH}$ adopted eight indicators: 1) green planning and design, 2) green open space, 3) green waste, 4) green building, 5) green transportation, 6) green energy, 7) green water, and 8) green community (Table 3). Among the eight indicators, green planning and design is the most important one. This indicator is a mandatory indicator for localities to be selected for P2KH: the "commitment" of the local government to revise the local spatial plan (RTRW) by allocating at least $30 \%$ of a city's total area for green open space (Ministry of Public Works, 2013a). However, from 2016 to 2020 this requirement was tightened by obligating "an already revised" RTRW within which $30 \%$ of a city's total area is already allocated for green open space. Following this RTRW-related requirement, the local government was later required to prepare a green city master plan and to sign an action plan agreement to implement the P2KH program (Ministry of Public Works, 2013b; Kirmanto et al., 2014).

The other important indicators are green open space and green community. In fact, the gist of $\mathrm{P} 2 \mathrm{KH}$ is the development of a park (green open space). Meanwhile, the green community indicator refers to the establishment of a green community forum or forum komunitas hijau (FKH) in each participating locality to raise public awareness toward green city development. Citizens were expected to support $\mathrm{P} 2 \mathrm{KH}$ by maintaining and utilizing the pilot park in various ways.

The other remaining five indicators were not compulsory and were, therefore, executed differently across different localities. Indeed, not all localities have fully implemented these five indicators. It is important to note that all of these indicators were executed in a rather narrow manner, in that the development of green waste, green energy, green building, green transportation, and green water took place inside and around the pilot park, rather than having a city-wide perspective.

\section{METHODS}

This study is an exploratory study as it does not intend to provide conclusive results, but rather to observe a specific research problem that will help us to have a better understanding of this problem (Swedberg, 2020). Exploratory research tends to focus on a specific phenomenon that few or no previous studies have focused on (Brown, 2006; Swedberg, 2020). As such, this type of research often forms the basis for more conclusive studies.

The fact that the application of green cities in the context of cities in the Global South has received marginal policy and scholarly attention would make this topic fit with the nature of exploratory research. In this study, we focus on the green city development in Indonesia. As noted earlier, the green city program $(\mathrm{P} 2 \mathrm{KH})$ was the most obvious nationwide program run under the urban sustainability framework. Instead of being a single model that can travel seamlessly across different cities worldwide (see Leducq and

TABLE 3 | Indicators of P2KH.

\begin{tabular}{|c|c|c|}
\hline No & Indicator & Description \\
\hline 3 & Green community & Establishing FKH in each participating locality \\
\hline 4 & Green waste & Providing trash bins and sorting systems (organic and non-organic waste) in the pilot park \\
\hline 5 & Green energy & Building solar cell-based lights in the pilot park \\
\hline 6 & Green building & $\begin{array}{l}\text { Constructing gazebos and park benches that have low emissions such as those made of non-metallic materials or wood in } \\
\text { the pilot park }\end{array}$ \\
\hline 8 & Green waste & Building parks that have water elements, such as ponds or fountains \\
\hline
\end{tabular}


Scarwell, 2020), we considered that green cities operate, and are embedded in a specific geographical context. Within such geographical situatedness, various components have interwoven and have altogether formed a set of particular opportunities and challenges for green cities to develop. To this end, three lenses proposed by Lechner et al. (2020) were used to gain better insights into the context-specifics underpinning green city development in Indonesia.

The data and information required for the analysis using the framework mentioned above were gathered from primary and secondary sources. Primary data were collected mainly through participant observation (Laurier, 2010) that was conducted by the first author from 2011 to 2015. Participant observation is viewed as part of ethnographic methods. Participant observation has been used in qualitative research as a tool for collecting data about people, processes, and other social settings where the researcher is immersed in the day-to-day activities of people under study. The overall objective of this method is to develop a holistic understanding of the phenomenon under study (DeWalt and DeWalt, 2002). While this method has a number of advantages, it also shares some disadvantages, inter alia different researchers can have different interpretations about what they observe because of the key informants chosen and researcher's individual interest in a social setting (DeMunck and Sobo, 1998; DeWalt and DeWalt, 2002). To reduce such bias, secondary sources were used to triangulate the findings based on the primary data. This secondary data were collected from relevant policy documents, statistical reports, official documents, and relevant studies.

According to Gold (1958), there are four stances of "observer" in participant observation. Based on this classification, the first author acted as "the observer as participant", implying that the researcher observed and interacted closely enough with members, without participating in the core activities of the members (see Adler and Adler, 1994: 380). Within the context of our paper, the first author was involved in $\mathrm{P} 2 \mathrm{KH}$ as part of the expert team hired by PUPR without directly influencing the core policymaking process. The researcher thus had the opportunity to interact with varying actors and parties at the national and local levels on different occasions (see Supplementary Appendix S1 for the detailed activities of the researcher).

To keep up with the progress of green cities' development within the remaining period of $\mathrm{P} 2 \mathrm{KH}$ implementation (2016-2020), some informal interviews were carried out with representatives of PUPR directly dealing with the implementation of the program. Meanwhile, in this case, the secondary sources were also used in concurrence not only to complement, but also to triangulate our findings based on the primary data. It should be noted here that there has been no significant change in the way the $\mathrm{P} 2 \mathrm{KH}$ program was deployed between these two periods.

\section{GREEN CITIES DEVELOPMENT IN INDONESIA}

\section{Urban Characteristics}

As widely noted, rapidly increasing rates of population growth and urbanization in many developing countries have presented clear and pressing threats to sustainability (e.g., Hardoy et al., 2001). Such phenomena are also clearly evident in Indonesia, particularly in the context of the country's major cities and metropolitan areas. Indeed, the Indonesian urban system is characterized by the domination of the country's largest metropolises with the Jakarta metropolitan area (or Jabodetabek) sitting atop the urban hierarchy (Indraprahasta and Derudder, 2019). In this section our aim is not to capture all urban typologies in Indonesia, but rather focus on those largest urban areas where threats to environmental sustainability are more apparent.

One clear environmental implication of rapid urbanization and sprawling process has been uncontrolled land use conversion, where large tracts of conservation and agricultural areas have been converted (Firman, 2002; Pribadi and Pauleit, 2015). For instance, between 1972 and 2012, the percentage of forestland decreased from $34.4 \%$ to $10.1 \%$ in Jabodetabek (Pribadi and Pauleit, 2015). Meanwhile, within the same period, urban land use increased from 9,373 ha to $223,953 \mathrm{ha}$, with an average annual growth rate of $8.2 \%$. Similar evidence can also be seen in the country's second largest urban agglomeration: the Surabaya metropolitan area. The percentage of built-up areas in Surabaya city and its two adjacent regions, i.e., Gresik and Sidoarjo, doubled between 1994 and 2012 (Katherina and Indraprahasta, 2019). In the case of Surabaya city, the urban land use increased from $43.2 \%$ in 1994 to $52.8 \%$ in 2003 and to $72.8 \%$ in 2012 . One of the major urban characteristics resulting from this sprawling process has been the blurring of urban-rural boundaries, leading to the emergence of desakota areas. This term was coined by McGee (1991) to depict a densely populated rural area with more urban-like characteristics, both in terms of built environment and socio-economic landscapes.

The expansion of urban agglomeration, to a significant degree, and has been facilitated by the development of transportation networks connecting the urban core to its surrounding areas. In Jabodetabek, despite continuous improvement of the public transportation system, people daily commute between their homes and workplaces, largely by using private vehicles (BPS, 2019). Similar phenomenon also occurs in other metropolitan areas in Indonesia, including Bandung metropolitan area (Supriyatin et al., 2020). The excessive use of private vehicles in Indonesian urban agglomerations has contributed to the increase of GHG emissions production, thus deteriorating the urban environment. In the case of Jakarta city, about $70 \%$ of the city's air pollution is contributed by the emissions produced by fossilfuel-generated cars and motorcycles (The Jakarta Post, 2018). Based on the World Air Quality Report, Jakarta is the most polluted capital city in Southeast Asia and the fifth most polluted capital city in the world in 2019 (IQAir, 2019). The air pollution level in Jakarta's surrounding regions, such as South Tangerang city and Bekasi city, is even worse than Jakarta. The 2020-2021 pandemic condition has indeed improved the air quality in the Indonesian capital due to some measures to restrict human mobility. However, no significant efforts have been made to change the trajectory of private vehicle reliance in the Jabodetabek area, let alone in Indonesia's other major metropolises. While this particular issue has caused serious 
environmental and health risks, it has been overlooked by the $\mathrm{P} 2 \mathrm{KH}$ program that largely focused on green open space provision.

Given the scale and pace of urbanization, the core cities of many metropolitan areas have increasingly become a place filled with concrete, asphalt, and cement, leaving little room for green open space. Cities such as Jakarta and Medan, for instance, only have less than $10 \%$ green open space of their total area vis-à-vis $30 \%$ green open space as mandated by the spatial planning law. In general, little progress has been made to alter the fate of urban green open space. As many plots of land are already owned by individuals, the most likely option is to optimize governmentowned land for green open space. This option has been also pursued by the $\mathrm{P} 2 \mathrm{KH}$ program, although there has been no evaluation of how and to what extent this program has significantly altered the green open space provision in Indonesian cities. Some anecdotal examples, including in the case of Surabaya, have shown the importance of engaging nongovernment actors, including citizens, and to help increase the area for green open space. On the other hand, to demand a greater role for private actors in this matter has been a challenging task as these actors tend to capitalize their plots of land in the midst of an increasingly competitive land market, resulting in rising land prices in the urban core (Kenichiro, 2015; Leitner and Sheppard, 2018). So, while some real estate companies have developed residential complexes for middle- and upper-classes with significant areas allocated for greenery, this practice tends to encourage "green gentrification" within the city's context.

\section{Biophysics}

One of the key elements of green cities dealing with urban ecological issues is green open space. In the Indonesian context, the green city program actually originated from a mandate to provide green open space at least 30\% of a city's total area in every municipality or regency. It was expected that green open space could play aesthetic and ecological functions to maintain the urban ecosystem. Both functions are important to support human well-being through the delivery of ecosystem services.

Green open space should be thoroughly planned and designed considering the city's structure and demand for ecosystem services, such as the provision of fresh water, clean air, comfort, and temperature. Every city faces different issues and challenges that should be addressed. On the other hand, each city also possesses different local ecological conditions. In such a situation, interaction between biotic and abiotic elements plays a key role since the provision of ecosystem services depends on the optimized circulation of water, energy, carbon, and nutrients. Therefore, designing green open spaces should be local sitespecific where the utilization of native plant species should be enhanced as they have been long adapted to the local environment. Furthermore, maintaining green spaces should be done regularly and properly as plants' health is crucial to support environmental health.

Unfortunately, the green city program or $\mathrm{P} 2 \mathrm{KH}$ in Indonesia was merely focused on the compliance of the minimum percentage of green open space. Instead of making integrative planning and design, the insertion of green open space into the local spatial plan was simply executed by incorporating remaining green open spaces and adding land parcels owned by the local government that could be transformed into new green open spaces. Government land was chosen to ensure the longterm maintenance of green spaces as well as to avoid land conversion. Consequently, the need for green open spaces and ecosystem services, which was local-site specific, has been less considered. The development of new green open spaces was simply done based on the aesthetic consideration as well as the proximity of government land to human settlements in order to support citizens' outdoor activities.

In practice, the $\mathrm{P} 2 \mathrm{KH}$ program only supported the development of a single urban park as a pilot project on the local government's land. It was expected that the project could stimulate the local government to develop the remaining planned green open spaces that were already included in the local spatial plan. However, this scenario did not go as expected due to a lack of commitment to fund this program after the support from the national program was over. Certainly, green open space which was developed by the $\mathrm{P} 2 \mathrm{KH}$ program was insufficient to support the improvement of the urban ecosystem.

As a result, there is a wide gap between $\mathrm{P} 2 \mathrm{KH}$ and the necessities to build green open spaces that are able to enhance ecosystem services. By this, we mean not only the quantity, but also the quality of green spaces, particularly related to the capability of green spaces to support urban environmental health and sustainability. In this sense, the variety of biophysic characteristics was barely considered.

Indonesia is a country with a very high diversity of tropical landscapes consisting of thousands of islands under different microclimate conditions and natural landscape compositions. The varied size of islands, landforms, and altitudes have given places for rich biodiversity. On the other hand, cities in Indonesia have different biophysical conditions as they are located in different geographical typologies, ranging from mountains, hills, valleys, plain areas, lowland, and coastal areas. These cities also have different sizes, ranging from small cities to mega-urban regions. This implies that the biophysical challenges vary between cities.

Still, as a tropical country located on the equator, Indonesia is characterized by heavy rainfall. Coupled with the sea level rise caused by global climate change, metropolitans, mostly located in the lowland, and coastal areas, are increasingly prone to flood. Meanwhile, cities with smaller sizes located in the upper areas are prone to landslides. Some cities in other areas are also disturbed by smoke haze caused by peatland and forest fires from their surrounding hinterlands, mainly during the dry season. Increasing temperature, pollutants, waste, and noise have also become common problems that have altogether threatened urban environmental health.

In order to cope with these issues, building urban green spaces capable of optimizing ecosystem services becomes more complicated. Restoring environmental conditions is often problematic due to the existence of various ecosystem types inhabited by rich biodiversity. It has become a great challenge when the GI and/or NBS approach as currently developed by green cities in the Global North would be fully adopted in the Indonesian green city program. 
Based on this biophysical perspective, just copying the successful story of green cities in the Global North could thus be misleading. More efforts are needed to build functional green open spaces given the country's more complex environmental system. On the other hand, the lack of knowledge, as well as financial and human resources, have also hampered these efforts. A priority setting can be proposed in developing green open space, particularly focusing on the main and common problem such as water management. As argued by some (Kooy et al., 2019; Lechner et al., 2020), water management is pivotal for reaching sustainability in South and Southeast Asian cities which are affected by the monsoon climate.

\section{Policy and Governance Context}

There are several elements promoted by the green city concepts within the policy and governance context. The first and foremost element is the presence of pro-environmental policy. As has been further emphasized, the implementation of such policy is strongly encouraged to be accompanied by knowledge co-creation as well as participatory and collaborative approaches. However, the form and degree of government support for the environmental aspect and how this pro-environmental policy is implemented are influenced by, among other things, the structure of governance, government vision, political landscape, and leadership style in each country.

In Indonesia, despite the country's decentralizing and democratizing system, the central government still plays a pivotal part in the development process that, to a certain extent, relates to the country's developmentalist root (Indraprahasta et al., 2018; Warburton, 2018; Hudalah et al., 2021). The central government's role includes the production of national-wide development frameworks and directives as well as the provision of technical and substantial assistance of such national initiatives to the local governments. The development of green cities (through the $\mathrm{P} 2 \mathrm{KH}$ program) is no exception. This most "noticeable" pro-environment urban strategy was initiated by the central government and was expected to be trialed across a large number of cities in the country.

As noted earlier, the development of green cities in Indonesia has not been backed up by a broader urban policy framework. Given this absence, Law 26/2007 on Spatial Planning has been used as the regulatory anchoring in the adoption of the green city concept, particularly the mandate to provide green open space to at least $30 \%$ of a city's total area. The utilization of this particular mandate as the main departure point, coupled with the lack of a clear sustainable cities vision, has resulted in a somewhat narrow reinterpretation of the green city conceptualization. This situation has been further aggravated by the actors involved in the policy making process at the national level. By this we mean that PUPR, being the initiator of and acting as the leading public agency in green cities development, has not invited other related ministries, including the Ministry of Environment and Forestry (KLHK), at an equal basis. This lack of inter-sectoral collaboration and institutional fragmentation has therefore dwarfed the relatively rich definition of a green city. As a result, the development of green cities in Indonesia has been deployed as a park-centered project.
From a governance perspective, PUPR's limited interpretation of the concept is also visible in the establishment of FKH at the local level. As one of the requirements for cities to be selected in the green city program, the local governments are obligated to form a green community, which is argued to ostensibly represent the participatory process of the program. The spatial planning system (Law 26/2007) promotes active participation by citizens in all stages of spatial planning process (i.e., planning, implementation, and control). However, while democracy has been given more space in Indonesia, participating citizens have been oftentimes brought on board to legitimate governmentinitiated purposes (Widianingsih and Morrell, 2007; Anindito et al., 2021). In the case of the green city initiative, the local government invited community leaders and environmental activists as representatives of citizens in the hope that they can maintain and use the pilot park developed by the central government. Citizens were, however, positioned more as users and were not involved in the broader policy making process, including in matters regarding where the park should be built, how the park should be designed, or, more broadly, and how the green city program would fit into the city's sustainability vision.

Recent discussion of green cities has paid great attention to the environmental "justice" issue, which also resonates with the "distributive" aspect of democratic urban governance (Anguelovski et al., 2018; Ghosh and Arora, 2021). The practice of $\mathrm{FKH}$, and of green city governance in general, hardly took this distributive aspect into consideration. The selection of representatives of citizens in FKH did not consider the representativeness of different social groups of citizens. Limited attention was thus given to the social diversity of a city, addressing how the development of the pilot park would yield equal benefits to all citizens, irrespective of their social group. The absence of this distributive or justice element can be also seen from a broader policy perspective. When taking measures concerning environmental issues, many (if not most) practices of spatial planning in Indonesia have treated these as a blanket phenomenon, thus disregarding how such challenges may have different implications to different groups of citizens living in different places within a city (Padawangi, 2012; Leitner et al., 2017). Meanwhile, the spatial planning law itself solely focuses on the provision of a minimum percentage of green open space without explicitly linking this mandate to a city's unique socio-economic landscape.

Another important challenge to optimally implement proenvironmental (urban) policy, particularly in many developing countries, is that economic factors, combined with political interests (vis-à-vis environmental considerations), often have more influence on the direction of development decisions. In Indonesia, practices of land development have been largely driven by neoliberal accumulation regimes (Gellert, 2015; Leitner and Sheppard, 2018; Dale, 2021). Combined with a lack of spatial planning law enforcement, market favoring policy has facilitated the commodification of land. Private developers have assumed a larger role in transforming the country's urban landscape through the development of industrial estates, multifunctional new towns, commercial complexes, and residential areas (e.g., Firman, 2004; Firman and Fahmi, 2017). Here, we should not only be aware of 
TABLE 4 | Different trajectories of developing potentialities of green cities in the global north and south.

\begin{tabular}{|c|c|c|}
\hline Indicators & $\begin{array}{l}\text { Green city in } \\
\text { the global north }\end{array}$ & $\begin{array}{l}\text { Green city in } \\
\text { the global south }\end{array}$ \\
\hline \multirow[t]{4}{*}{ Urbanization } & Green-compact-smart city & Interdependency of urban-rural system \\
\hline & Developing various types of green spaces & Focusing on edible/productive green spaces (urban dan peri-urban agriculture) \\
\hline & Reducing mobility & Facilitating mobility via mass rapid transportation \\
\hline & Compact urban form & Polycentric urban from \\
\hline \multirow[t]{3}{*}{ Biophysics } & Developing GI and NBS for supporting various ES & Developing Gl and NBS for water resource management \\
\hline & Integration of green and grey infrastructures & Integration of green and blue spaces \\
\hline & High-technology and high-cost maintenance of GI and NBS & Public participation in building and maintaining $\mathrm{Gl}$ and NBS \\
\hline \multirow[t]{2}{*}{ Governance } & Participation and collaborative actions & Multi-actors and multi-level governance \\
\hline & Aiming to provide ecosystem services & Aiming to deal with multidimensional issues in achieving SDGs \\
\hline
\end{tabular}

the undesirable consequences of such land development to a city's increasing environmental pressure, but also to the widening of environmental injustice within a city. Large-scale housing complexes constructed for middle- and upper-classes, for instance, have resulted in spatial segregation and fragmentation that have largely benefited the rich (Winarso et al., 2015). Mostly located in an area with a better natural landscape in the context of Indonesia's highly urbanized metropolises, the inhabitants living within these enclaved complexes enjoy a high value of green spaces per capita that leads to much better ecosystem services. On the other hand, on a city (and metropolitan) scale, the total area of green spaces has continued to decrease as a result of uncontrolled land use conversion.

The large-scale urban and infrastructure transformation has also been shaped by the neoliberal developmentalist vision of the state. A notable example would be the recent Trans Java Expressway development in Java's North Cost (Hudalah et al., 2020). Having the intention to spur interregional connectivity and economic growth in Indonesia's most populated island, this state-led megaproject may increase the vulnerability of cities located along the coastline to environmental pressures, most notably flooding and land subsidence (Sarah and Soebowo, 2018; Handayani et al., 2020). Such land development has also often sacrificed the everyday life of communities at the margin even though it is carried out under the environmental protection banner. The most recent example would be the climate change mitigation plan in the Jakarta Bay area that aims to protect the coast from sea level rise. This plan includes the mega-project development of a giant seawall with an integrated new town (comprising residential, commercial, and recreational spaces) branded as part of Jakarta's global city imaginary at the expense of the urban poor and fishing communities (Padawangi, 2012; Leitner et al., 2017).

While being a central government initiative, the state of policy and governance of green cities vary across cities. In decentralizing Indonesia, the fate of green cities, or of urban sustainability more broadly, depends on the initiative and efforts taken by the local governments as they have been given more room in steering their local development trajectory (Tarigan and Sagala, 2018). While many cities in Indonesia focus on reactive and short-term policy solutions, some anecdotal examples have exhibited the importance of taking continuous concrete steps to mitigate environmental challenges. A prominent example would be Surabaya, a city that is widely known for its abundant presence of green open spaces and community-based waste management. The city's current outstanding status was not achieved overnight, but is rather a constant ongoing process that started in 2002 under the leadership of mayor Bambang Dwi Hartono (Novalia et al., 2018). One of these earliest efforts was the merging of the Cleaning Department (Dinas Kebersihan) and Parks Department (Dinas Pertamanan) under Regional Law 14/ 2005, known there onward as Dinas Kebersihan dan Pertamanan (DKP). Another important aspect is the ability of the local governments to facilitate collaboration (Tarigan and Sagala, 2018). Such mode of governance creates a window of opportunity for generating more innovative ideas and solutions as well as co-sharing different resources in addressing environmental challenges. Balikpapan, for instance, has partnerships with at least 10 cities in Indonesia and with a number of national and international agencies, including Local Governments for Sustainability South-East Asia (ICLEI) and the Association of Indonesian Cities under United Nations Habitat funds (Tarigan and Sagala, 2018). In the case of Surabaya, the sister city cooperation with Kitakyushu, Japan, that was launched in 2002, has laid a learning platform for Surabaya to govern the city's sustainability path (Kurniawan et al., 2013; Novalia et al., 2018). These multiple cities and institutions' collaborations have altogether promoted knowledge sharing and co-learning processes. Meanwhile, Palembang's city government has established mutual linkages with educational institutions and private sectors to support the city's low-carbon development (Tarigan and Sagala, 2018). Many local governments in Indonesia, however, are still grappling with the practices of participatory and collaborative mode of governance (Indraprahasta et al., Forthcoming).

\section{DISCUSSION AND CONCLUSION}

The three aspects discussed above have explicated the geographical situatedness of green cities in Indonesia. In an increasingly globalized and interconnected world, the diffusion of blueprints for urban development, including green cities, across countries have escalated. As a result, various urban models and jargon have spread like wildfire: policy makers are 
racing to adopt a variety of global labels into the urban agenda in their respective countries and cities. In these practices of "worlding cities" (Roy and Ong, 2011), cities in the Global North have oftentimes become exemplary models to mimic. In this paper, we argue for the need to better understand the contextual specifics within which cities are located as there is no one-size-fits-all urban model.

The green city concept offers some opportunities for urban sustainability. In the Global North, the conceptualization of the green city has continued to evolve and intersected with newer environmental approaches in urban planning, including ES, GI, and NBS. It has also adopted some principles of other urban concepts such as compact city and smart city. From the case of Indonesia, it can be gleaned that the recent experimentation of green city development seems to have followed its own trajectory. Such a trajectory has been a result of the particular way the green city concept has been (re)interpreted and localized. To a certain degree, this has also been a result of the geographical situatedness of Indonesia, particularly relating to the country's urban sustainability policy. In our reading, other contextual aspects, particularly urbanization patterns and processes as well as biophysical characteristics, tend to be overlooked in the green city's adoption process.

With regard to Indonesia's reinterpretation of a green city, it is clear the concept has been adopted in a somewhat narrow manner centered around the provision of parks, a concern that is actually closer to the "garden city" concept. While the concept has ostensibly adopted the holistic vision of a green city, i.e., represented by the use of a number of green city indicators, the implementation of the concept can be seen as an urban placebo, where it has not heralded any significant intervention in terms of scale and urban, and spatial impact. Needless to say, Indonesia's adoption of a green city does not seem to be thought of as a systemic approach to the urban system, which has resulted from technocratic aspirations combined with the lack of longterm visioning of typical project-based activities.

However, in our view, the green city concept still endows some potentialities to achieve urban sustainability in the country by making some relevant adjustments. So, regardless of its limitation in terms of the concept adoption between 2011 and 2020, here we also intend to argue that further experimentation of green cities should appreciate the context specifics of Indonesian cities that may exhibit different characteristics from those of the Global North. It should be noted, however, that given the nature of our study, we did not intend to offer an archetypal model of green cities in Indonesia. Rather, from our previous discussion concerning the three aspects, we can sketch why a one-sizefits-all urban model does not exist and how and to what extent the green city concept can be contextually adopted.

First, regarding urbanization issues, green cities in the Global North were planned to be compact so as to expand areas allocated for green spaces and to reduce emissions produced by (mostly) private vehicles. However, urbanization in the Global South, including Indonesia, tends to have a sprawl pattern that form a mix of urban-rural land use, widely known as desakota. Following the trajectory of green cities in the Global North would, therefore, be problematic. Given this urban-rural relation, green cities as developed in the Global North can be adopted by also acknowledging the rural land uses as part of the urban system that produce ecosystem services. Most of these rural land uses are indeed farmland. With the application of good agricultural practices, farmland can also play a key role in environmental improvement as well as food security and income generation. Edible or productive green spaces could become a solution to provide ecosystem services. Another issue that should also be noted would be environmental justice as low-density settlements with larger green spaces are usually found in high-class housing complexes, mostly located in the peri-urban areas. Meanwhile, with regard to the emissions produced by private car-dependent commuting, mass public transportation with lower emissions can be developed to connect the urban core with settlements in the peri-urbans. Furthermore, encouraging polycentric urban form can be an alternative future metropolitan development to reduce commuting behavior (Hudalah and Firman, 2012). It is worth noting that, stimulated by the current pandemic situation, the change of work behavior from work from office to work from home has been proven to function well and to reduce emissions (Rendana and Komariah, 2021).

Second, mainstreaming GI and NBS has become a new trend in developing green cities in the Global North. Some ideas certainly can be adopted for developing green cities in the Global South, especially in planning and designing urban green infrastructures to provide ecosystem services for the public. However, as the bio-physic condition of cities in the Global South varies in terms of ecosystem types and biodiversity richness, priorities should be established. Particularly for Indonesia and tropical monsoon countries, water management is a key element for reaching sustainability (Kooy et al., 2019; Lechner et al., 2020). Therefore, GI and NBS approaches should be focused on storm water management, including restoring watershed quality from upstream to downstream. In parallel, waste management should be of concern as it has a close relationship with water management issues. In this case, green and blue spaces should be planned in an integrated manner and be included in the spatial planning vis-à-vis focusing on building parks or gardens to fulfill $30 \%$ green open space as mandated by the Indonesian spatial planning law. Another important aspect is developing multifunctional green and blue spaces vis-à-vis building green spaces with high technology and high-cost maintenance as in the Global North cities (e.g., roof garden, vertical garden, and green façade, etc.). In our view, this effort is crucial as most cities in the Global South have a lack of financial capacity. It is also expected that by building multifunctional spaces, communities and other participating actors would be more interested in getting involved in maintaining these green and blue spaces.

Third, participation and a collaborative approach is a prerequisite in developing green cities in the Global North. Such an approach is indeed ideal and should be adopted. However, the role of government is still very much dominant in the Global South cities. In addition to this, fragmented governance is also clearly visible in the context of the Indonesian green city program. Multi-level and multi-actor governance should be encouraged by considering horizontal and 
vertical boundaries of decision-making (Pauleit et al., 2021). This can be done if the green city program was not simply seen as an effort to reach $30 \%$ green open space. Rather, green cities should be positioned as an integral part of a broader urban agenda: climate change adaptation and mitigation, achieving SDGs (particularly the $11^{\text {th }}$ goal of SGDs), and increasing the quality of life and urban productivities, just to name a few. Such an integrated vision is therefore expected to involve other related government institutions outside PUPR. These institutions include multi-sectors or multidepartments at the national and local levels as well as other actors outside the government at different geographical scales.

Taken together, this paper has proposed some key points that can be taken into consideration in adopting and developing green cities in the Global South through the lens of urbanization, biophysics, and governance aspects. These key points are summarized in Table 4. Local characteristics and geographical situatedness of cities should be considered in this adoption process vis-à-vis simply mimicking green cities conceptualized and developed from and in the Global North. Other lenses can be also employed to expand the perspective offered by this paper. These lenses may include social, cultural, and economic aspects. Our main intention here has been to emphasize that adjustments

\section{REFERENCES}

Acuto, M., Parnell, S., and Seto, K. C. (2018). Building a Global Urban Science. Nat. Sustain. 1, 2-4. doi:10.1038/s41893-017-0013-9

Adler, P. A., and Adler, P. (1994). "Observation Techniques," in Handbook of Qualitative Research. Editors N. K. Denzin and Y. S. Lincoln (Thousand Oaks, CA: Sage), 377-392.

Ahmed, Z., Wang, Z., and Ali, S. (2019). Investigating the Non-linear Relationship between Urbanization and CO2 Emissions: An Empirical Analysis. Air Qual. Atmos. Health 12, 945-953. doi:10.1007/s11869-019-00711-x

Alisjahbana, A. S., and Murniningtyas, E. (2018). Tujuan Pembangunan Berkelanjutan di Indonesia: Konsep, Target dan Strategi Implementasi. Bandung: Unpad Press.

Anguelovski, I., Connolly, J., and Brand, A. L. (2018). From Landscapes of utopia to the Margins of the green Urban Life. City 22 (3), 417-436. doi:10.1080/ 13604813.2018.1473126

Anindito, D. B., Sagala, S. A. H., and Tarigan, A. K. M. (2021). E-musrenbang: a Digital Framework for Local Participatory Planning at the Community Level. Int. Dev. Plann. Rev. ahead-of-print, 1-26. doi:10.3828/idpr.2021.5

Aronson, M. F., Lepczyk, C. A., Evans, K. L., Goddard, M. A., Lerman, S. B., Macivor, J. S., et al. (2017). Biodiversity in the City: Key Challenges for Urban green Space Management. Front. Ecol. Environ. 15 (4), 189-196. doi:10.1002/ fee. 1480

Artmann, M., Kohler, M., Meinel, G., Gan, J., and Ioja, I.-C. (2019). How Smart Growth and green Infrastructure Can Mutually Support Each Other - A Conceptual Framework for Compact and green Cities. Ecol. Indicators 96 (June), 10-22. doi:10.1016/j.ecolind.2017.07.001

Bps [Indonesia Statistical Office] (2019). Statistik Komuter Jabodetabek: Hasil Survei Komuter Jabodetabek 2019. Jakarta: BPS.

Breuste, J., Artmann, M., Ioja, C., and Qureshi, S. (2020). The Green City: General ConceptMaking Green Cities Concepts, Challenges and Practices. Springer, 1-15. doi:10.1007/978-3-030-37716-8_1

Brown, R. B. (2006). Doing Your Dissertation in Business and Management: The Reality of Research and Writing. London: Sage Publications.

Dahiya, B. (2012). Cities in Asia, 2012: Demographics, Economics, Poverty, Environment and Governance. Cities 29, S44-S61. doi:10.1016/j.cities.2012. 06.013

Dale, C. J. P. (2021). Komodo vs Pembangunanisme Kolonial. Majalah Tempo. Available at https://majalah.tempo.co/read/investigasi/162227/kolom-wisata- are required to develop green cities in different socio-ecological landscapes.

\section{DATA AVAILABILITY STATEMENT}

The datasets generated during and/or analyzed during the current study are available from the corresponding author upon reasonable request.

\section{AUTHOR CONTRIBUTIONS}

All authors have contributed equally to the work and approved it for publication.

\section{SUPPLEMENTARY MATERIAL}

The Supplementary Material for this article can be found online at: https://www.frontiersin.org/articles/10.3389/fenvs.2022.787204/ full\#supplementary-material

eksklusif-komodo-mirip-cara-belanda-mengembangkannya (Accessed 2 January 2021).

Derkzen, M. L., Van Teeffelen, A. J., Nagendra, H., and Verburg, P. H. (2017) Shifting Roles of Urban green Space in the Context of Urban Development and Global Change. Curr. Opin. Environ. Sustainability 29, 32-39. doi:10.1016/j. cosust.2017.10.001

DeWalt, K. M., and DeWalt, B. R. (2002). Participant Observation: A Guide for Fieldworkers. Walnut Creek, CA: AltaMira Press.

EC (2013). Building a green Infrastructure for Europe. [European Commission] Available at https://ec.europa.eu/environment/nature/ecosystems/docs/green infrastructure_broc (Accessed September 10, 2021).

EIU (2012). The Green City Index. Siemens AG Corporate Communications and Government Affairs Wittelsbacherplatz. München 2, 80333. [Economist Intelligent Unit].

El Ghorab, H. K., and Shalaby, H. A. (2016). Eco and Green Cities as New Approaches for Planning and Developing Cities in Egypt. Alexandria Eng. J. 55 (1), 495-503. doi:10.1016/j.aej.2015.12.018

Elmqvist, T., and Mcdonald, R. I. (2013). Urbanization Biodiversity and Ecosystem Services: Challenges and Opportunities.

Estoque, R. C., and Murayama, Y. (2015). Intensity and Spatial Pattern of Urban Land Changes in the Megacities of Southeast Asia. Land Use Policy 48, 213-222. doi:10.1016/j.landusepol.2015.05.017

Firman, T., and Fahmi, F. Z. (2017). The Privatization of Metropolitan Jakarta's (Jabodetabek) Urban Fringes: The Early Stages of "Post-Suburbanization" in Indonesia. J. Am. Plann. Assoc. 83 (1), 68-79. doi:10.1080/01944363.2016. 1249010

Firman, T. (2004). Major Issues in Indonesia's Urban Land Development. Land Use Policy 21 (4), 347-355. doi:10.1016/j.landusepol.2003.04.002

Firman, T. (2002). Urban Development in Indonesia, 1990-2001: from the Boom to the Early Reform Era through the Crisis. Habitat Int. 26, 229-249. doi:10.1016/ s0197-3975(01)00045-5

Garcia-Lamarca, M., Anguelovski, I., Cole, H., Connolly, J. J., Argüelles, L., Baró, F., et al. (2021). Urban green Boosterism and City Affordability: For Whom Is the 'branded' green city. Urban Stud. 58 (1), 90-112. doi:10.1177/0042098019885330

Gellert, P. K. (2015). Palm Oil Expansion in Indonesia: Land Grabbing as Accumulation by Dispossession. Curr. Perspect. Soc. Theor. 34, 6599. doi:10. 1108/s0278-120420150000034004

Ghosh, B., and Arora, S. (2021). Smart as (Un)democratic? the Making of a Smart City Imaginary in Kolkata, India. Environ. Plann. C: Polit. Space, 239965442110275. doi:10.1177/23996544211027583 
Gold, R. L. (1958). Roles in Sociological Field Observations. Social Forces 36, 217-223. doi:10.2307/2573808

Handayani, W., Chigbu, U. E., Rudiarto, I., and Putri, I. H. S. (2020). Urbanization and Increasing Flood Risk in the Northern Coast of Central Java-Indonesia: An Assessment towards Better Land Use Policy and Flood Management. Land 9, 343. doi:10.3390/land 9100343

Hansen, R., Olafsson, A. S., Van Der Jagt, A. P. N., Rall, E., and Pauleit, S. (2019). Planning Multifunctional green Infrastructure for Compact Cities: What Is the State of Practice. Ecol. Indicators 96 (November), 99-110. doi:10.1016/j.ecolind.2017.09.042

Hardiman, R. (2020). China and Natural Based Solution. Available at: https://www. regreen-project.eu/news/china-and-nature-based-solutions/(Accessed September 110, 2021).

Hardoy, J. E., Mitlin, D., and Satterthwaite, D. (2001). Environmental Problems in an Urbanizing World: Finding Solutions in Cities in Africa, Asia and Latin America. 2nd ed. Routledge. doi:10.4324/9781315071732

Hudalah, D., and Firman, T. (2012). Beyond Property: Industrial Estates and postsuburban Transformation in Jakarta Metropolitan Region. Cities 29 (1), 40-48. doi:10.1016/j.cities.2011.07.003

Hudalah, D., Octifanny, Y., Talitha, T., Firman, T., and Phelps, N. A. (2020). From Metropolitanization to Megaregionalization: Intentionality in the Urban Restructuring of Java's North Coast, Indonesia. J. Plann. Edu. Res., 0739456X2096740. doi:10.1177/0739456X20967405

Hudalah, D., Talitha, T., and Lestari, S. F. (2021). Pragmatic State Rescaling: The Dynamics and Diversity of State Space in Indonesian Megaproject Planning and Governance. Environ. Plann. C: Polit. Space, 239965442110309. doi:10. $1177 / 23996544211030935$

Indraprahasta, G. S., Derudder, B., and Koelemaij, J. (2018). Global-local Dynamics in the Transformation of the Jakarta Metropolitan Area into a Global CityRegion. disP - Plann. Rev. 54 (3), 52-62. doi:10.1080/02513625.2018.1525212

Indraprahasta, G. S., and Derudder, B. (2019). World City-Ness in a Historical Perspective: Probing the Long-Term Evolution of the Jakarta Metropolitan Area. Habitat Int. 89, 102000. doi:10.1016/j.habitatint.2019.102000

Indraprahasta, G. S., Fahmi, F. Z., and Alamsyah, P. (Forthcoming). "The Dynamics of Multi-Scalar Networks Underlying the Creative City Process: The Case of Bandung," in Routledge Handbook of Urban Indonesia. Editors S. Roitman and D. Rukmana (Abingdon, UK \& New York: Routledge).

IQAir (2019). World Air Quality Report. Goldach: IQAir.

Jafari, Y., Othman, J., and Nor, A. H. S. M. (2012). Energy Consumption, Economic Growth and Environmental Pollutants in Indonesia. J. Pol. Model. 34, 879-889. doi:10.1016/j.jpolmod.2012.05.020

Jambeck, J. R., Geyer, R., Wilcox, C., Siegler, T. R., Perryman, M., Andrady, A., et al. (2015). Plastic Waste Inputs from Land into the Ocean. Science 347 (6223), 768-771. doi:10.1126/science.1260352

Joga, N., and Ismaun, I. (2011). RTH 30 \%! Resolusi (Kota) Hijau. Jakarta: Gramedia Pustaka Utama.

Kahn, C. (1982). "Historical Roots: The History of Community Gardening," in A Handbook of Community Gardening. Editor S. Naimark (New York, NY: Charles Scribner's Sons), 11-16.

Katherina, L. K., and Indraprahasta, G. S. (2019). Urbanization Pattern in Indonesia's Secondary Cities: Greater Surabaya and its Path toward a Megacity. IOP Conf. Ser. Earth Environ. Sci. 338, 012018. doi:10.1088/17551315/338/1/012018

Kenichiro, A. (2015). Jakarta "Since Yesterday": The Making of the post-new Order Regime in an Indonesian metropolis. Southeast Asian Stud. 4 (3), 445-486.

Kirmanto, D., Ernawi, I. S., and Djakapermana, R. D. (2014). Indonesia green city Development Program: An Urban Reform. Paper Presented at the 48th ISOCARP Congress, 10-13 September 2012. Perm Russia.

KLH (1997). Agenda 21 Indonesia: Strategi Nasional Untuk Pembangunan Berkelanjutan. Jakarta: KLH. Ministry of Environment.

KLH (2002). Dari krisis menuju keberlanjutan meniti jalan pembangunan berkelanjutan di Indonesia: Tinjauan pelaksanaan Agenda 21. Jakarta: KLH. Ministry of Environment.

Kooy, M., Furlong, K., and Lamb, V. (2020). Nature Based Solutions for Urban Water Management in Asian Cities: Integrating Vulnerability into Sustainable Design. Int. Dev. Plann. Rev. 42 (3), 381-390. doi:10.3828/idpr.2019.17

Kurniawan, T. A., Puppim de Oliveira, J., Premakumara, D. G. J., and Nagaishi, M. (2013). City-to-city Level Cooperation for Generating Urban Co-benefits: the Case of Technological Cooperation in the Waste Sector between Surabaya
(Indonesia) and Kitakyushu (Japan). J. Clean. Prod. 58, 43-50. doi:10.1016/j. jclepro.2013.08.002

Laurier, E. (2010). "Participant Observation," in Key Methods in Geography. Editors N. Clifford, S. French, and G. Valentine (London: Sage), 116-130.

Lechner, A. M., Gomes, R. L., Rodrigues, L., Ashfold, M. J., Selvam, S. B., Wong, E. P., et al. (2020). Challenges and Considerations of Applying Nature-Based Solutions in Low- and Middle-Income Countries in Southeast and East Asia. Blue-Green Syst. 2 (1), 331-351. doi:10.2166/bgs.2020.014

Leducq, D., and Scarwell, H.-J. (2020). Green-city Models as an Urban Strategy: Hanoi between International Practices and Local Assemblage. Town Plann. Rev. 91 (4), 437-456. doi:10.3828/tpr.2020.25

Leitner, H., Colven, E., and Sheppard, E. (2017). "Ecological Security for Whom? the Politics of Flood Alleviation and Urban Environmental justice in Jakarta, Indonesia," in The Routledge Companion to the Environmental Humanities. Editors U. Heise, J. Christensen, and M. Niemann (London: Routledge), 194-205.

Leitner, H., and Sheppard, E. (2018). From Kampungs to Condos? Contested Accumulations through Displacement in Jakarta. Environ. Plan. A. 50 (2), 437-456. doi:10.1177/0308518x17709279

Lengeweg, F., Hilderink, H., and Maas, R. (2000). Urbanisation, Industrialisation, and Sustainable Development. Research for Man and Environment. Tokyo: United Nations University.

Li, K., and Lin, B. (2015). Impacts of Urbanization and Industrialization on Energy consumption/CO2 Emissions: Does the Level of Development Matter. Renew. Sustain. Energ. Rev. 52, 1107-1122. doi:10.1016/j.rser.2015.07.185

Liendfield, M., and Steinberg, F. (2012). Green Cities. Mandaluyong City: ADB Publication.

Masripatin, N., Rachmawaty, E., Suryanti, Y., Setyawan, H., Farid, M., and Iskandar, N. (2017). Strategi Implementasi NDC (Nationally Determined Contribution). Jakarta: Ministry of Environmental Affairs and Forestry.

McGee, T. G. (1991). “The Emergence of Desakota Regions in Asia: Expanding a Hypothesis," in The Extended Metropolis: Settlement Transition in Asia. Editors N. Ginsburg, B. Koppel, and T. G. McGee (Honolulu: University of Hawaii Press), 3-25.

MEA (2005). Ecosystems and Human Wellbeing. Washington, DC: Island Press. Millennium Ecosystem Assessment.

Ministry of Public Works (2013a). Manual Kegiatan Program Pengembangan Kota Hijau 2013. Jakarta: Direktorat Jenderal Penataan Ruang, Kementerian Pekerjaan Umum

Ministry of Public Works (2013b). Panduan Pengembangan Kota Hijau 2013. Jakarta: Direktorat Jenderal Penataan Ruang, Kementerian Pekerjaan Umum.

Moore, S. (2006). Forgotten Roots of the Green City: Subsistence Gardening in Columbus, Ohio, 1900-1940. Urban Geogr. 27 (2), 174-192. doi:10.2747/02723638.27.2.174

Nesshöver, C., Assmuth, T., Irvine, K. N., Rusch, G. M., Waylen, K. A., Delbaere, B., et al. (2017). The Science, Policy and Practice of Nature-Based Solutions: An Interdisciplinary Perspective. Sci. Total Environ. 579, 1215-1227. doi:10.1016/j. scitotenv.2016.11.106

Novalia, W., Rogers, B. C., Bos, J. J., and Brown, R. R. (2018). “Diagnosing Strategic Influences of Different Agents in Governing Transition towards green city in Surabaya, Indonesia," in Paper presented at the Earth Systems Governance Conference, 5-8 November 2018, Utrecht, the Netherlands.

Pace, R., Churkina, G., and Rivera, M. (2016). How green Is a "Green City"? A Review of Existing Indicators and Approaches. IASS Working Paper. December 2016. doi:10.2312/iass.2016.035

Padawangi, R. (2012). "Climate Change and the north Coast of Jakarta: Environmental justice and the Social Construction of Space in Urban Poor Communities," in Urban Areas and Climate Change (Research in Urban Sociology. Editor W. G. Holt (Bingley, UK: Emerald), 12, 321-339.

Pankaja, M. S., and Nagendra, H. N. (2015). Green city Concept - as New Paradigm in Urban Planning. Int. J. Eng. Sci. 4 (10), 55-60.

Pauleit, S., Hansen, R., and Pribadi, D. O. (2021). Editorial: Transformative Urban Greening: Advancing Green Space Governance. Front. Sustain. Cities 3 (September), 1-3. doi:10.3389/frsc.2021.735918

Pauleit, S., Zölch, T., Hansen, R., Randrup, T. B., and Konijnendijk van den Bosch, C. (2017). "Nature-Based Solutions and Climate Change - Four Shades of Green," in Nature-based Solutions to Climate Change Adaptation in Urban Areas, Theory and Practice of Urban Sustainability Transitions. Editors 
N. Kabisch, H. Korn, J. Stadler, and A. Bonn (Springer), 29-49. doi:10.1007/ 978-3-319-56091-5_3

Pribadi, D. O., and Pauleit, S. (2015). The Dynamics of Peri-Urban Agriculture during Rapid Urbanization of Jabodetabek Metropolitan Area. Land Use Policy 48, 13-24. doi:10.1016/j.landusepol.2015.05.009

Rendana, M., and Komariah, L. N. (2021). The Relationship between Air Pollutants and COVID-19 Cases and its Implications for Air Quality in Jakarta, Indonesia. Jpsl 11 (1), 93-100. doi:10.29244/jpsl.11.1.93-100

Richter, B., and Behnisch, M. (2019). Integrated Evaluation Framework for Environmental Planning in the Context of Compact green Cities. Ecol. Indicators 96 (2), 38-53. doi:10.1016/j.ecolind.2018.05.025

Roy, A., and Ong, A. (2011). Worlding Cities: Asian Experiments and the Art of Being Global. West Sussex: Blackwell Publishing.

Sachs, J. D. (2015). The Age of Sustainable Development. New York: Columbia University Press.

Salim, W., and Hudalah, D. (2020). "Urban Governance Challenges and Reforms in Indonesia: Towards a New Urban Agenda," in New Urban Agenda in AsiaPacific: Governance for Sustainable and Inclusive Cities. Editors B. Dahiya and A. Das (Singapore: Springer), 163-181. doi:10.1007/978-981-13-6709-0_6

Sarah, D., and Soebowo, E. (2018). Land Subsidence Threats and its Management in the North Coast of Java. IOP Conf. Ser. Earth Environ. Sci. 118, 012042. doi:10.1088/1755-1315/118/1/012042

Sarosa, W., Isnutomo, M. D., Virant, G. E., Sarahidha, D., and Susetyo, N. A. (2017). Panduan Praktis Implementasi Agenda Baru Perkotaan Untuk Kota Berkelanjutan Indonesia. Jakarta: Ministry of Public Works and Housing.

Schwarz, N., Moretti, M., Bugalho, M. N., Davies, Z. G., Haase, D., Hack, J., et al. (2017). Understanding Biodiversity-Ecosystem Service Relationships in Urban Areas: A Comprehensive Literature Review. Ecosyst. Serv. 27, 161-171. doi:10. 1016/j.ecoser.2017.08.014

Shen, Z., and Fitriaty, P. (2018). "Overview: Green City Planning and Practices in Asian Cities," in Green City Planning and Practices in Asian Cities, Strategies for Sustainability, 1-16. doi:10.1007/978-3-319-70025-0_1

Supriyatin, R., Pravitasari, A. E., and Pribadi, D. O. (2020). Pola Interaksi Spasial serta Karakteristik Individu dan Rumah Tangga Komuter antar Kabupaten/Kota di Bandung Raya. Jp2Wd 4 (2), 113-133. doi:10.29244/jp2wd.2020.4.2.113-133

Swedberg, R. (2020). "Exploratory Research," in The Production of Knowledge. Editors C. Elman, J. Gerring, and J. Mahoney (Cambridge: Cambridge University Press), 17-41. doi:10.1017/9781108762519.002

Tarigan, A. K. M., and Sagala, S. (2018). The Pursuit of Greenness: Explaining LowCarbon Urban Transformation in Indonesia. Int. Plann. Stud. 23 (4), 408-426. doi:10.1080/13563475.2018.1513360

The Jakarta Post (2018). Air Pollution in Jakarta, an Invisible Health Threat. Available at: https://www.thejakartapost.com/adv/2018/08/15/air-pollution-injakarta-an-invisible-health-threat.html. (Accessed 15 August).

UNDESA (2018). World Urbanization Prospects: The 2018 Revision. Online Edition. United Nations, Department of Economic and Social Affairs, Population Division.

V. C. DeMunck and E. J. Sobo (Editors) (1998). Using Methods in the Field: A Practical Introduction and Casebook (Walnut Creek, CA: AltaMira Press).
Venkatesh, G. (2013). A Critique of the European Green City Index. J. Environ Plann. Manage. 57 (3), 317-328. doi:10.1080/09640568.2012.741520

Warburton, E. (2018). A New Developmentalism in Indonesia. Ae 35 (3), 355-368. doi:10.1355/ae35-3c

Warner, S. B. (1987). To Dwell Is to Garden: A History of Boston's Community Gardens. Boston, MA: Northeastern University Press.

Widianingsih, I., and Morrell, E. (2007). Participatory Planning in Indonesia. Pol. Stud. 28 (1), 1-15. doi:10.1080/01442870601121320

Wijaya, A., Chrysolite, H., Ge, M., Wibowo, C., Pradana, A., Utami, A., et al. (2017). How Can Indonesia Achieve its Climate Change Mitigation Goal? an Analysis of Potential Emissions Reductions from Energy and Land-Use Policies. Working Paper. Jakarta, Indonesia: World Resources Institute. Available online at www.wri.org/publication/how-can-indonesia-achieveitsclimate-goal.

Winarso, H., Hudalah, D., and Firman, T. (2015). Peri-urban Transformation in the Jakarta Metropolitan Area. Habitat Int. 49, 221-229. doi:10.1016/j. habitatint.2015.05.024

World Bank (2020). Urban Development. Available at https://www.worldbank. org/en/topic/urbandevelopment/overview.

Xie, L., and Bulkeley, H. (2020). Nature-based Solutions for Urban Biodiversity Governance. Environ. Sci. Pol. 110, 77-87. doi:10.1016/j. envsci.2020.04.002

Zain, A. M., and Kencana, I. P. (2010). "Keberagaman kota dan pembangunan perkotaan di Indonesia: Peran ruang terbuka hijau dalam lingkungan hidup," in Ministry of Public Works, Status Perkembangan Perkotaan Indonesia 2010: Mengelola Keberagaman Dan Kesejangan Pembangunan Kota (Jakarta: Direktorat Jenderal Penataan Ruang, Kementerian Pekerjaan Umum), 2: 34-42:48.

Zinkernagel, R., Evans, J., and Neij, L. (2018). Applying the SDGs to Cities: Business as Usual or a New Dawn. Sustainability 10 (9), 3201. doi:10.3390/ su10093201

Conflict of Interest: The authors declare that the research was conducted in the absence of any commercial or financial relationships that could be construed as a potential conflict of interest.

Publisher's Note: All claims expressed in this article are solely those of the authors and do not necessarily represent those of their affiliated organizations, or those of the publisher, the editors and the reviewers. Any product that may be evaluated in this article, or claim that may be made by its manufacturer, is not guaranteed or endorsed by the publisher.

Copyright $\odot 2022$ Zain, Pribadi and Indraprahasta. This is an open-access article distributed under the terms of the Creative Commons Attribution License (CC BY). The use, distribution or reproduction in other forums is permitted, provided the original author(s) and the copyright owner(s) are credited and that the original publication in this journal is cited, in accordance with accepted academic practice. No use, distribution or reproduction is permitted which does not comply with these terms. 